\title{
Role of oestradiol in the regulation of the seasonal antler cycle in female reindeer, Rangifer tarandus
}

\author{
G. A. Lincoln ${ }^{1}$ and N. J. C. Tyler ${ }^{2 *}$ \\ ${ }^{1} M R C$ Reproductive Biology Unit, Centre for Reproductive Biology, 37 Chalmers Street, Edinburgh EH3 9EW, UK; and \\ ${ }^{2}$ Department of Arctic Biology, Institute of Medical Biology, University of Tromsø, 9037 Tromsø, Norway
}

\begin{abstract}
Reindeer (or caribou), Rangifer tarandus, is the only extant species of deer in which females as well as males normally develop antlers that are cast and regrown each year. This study investigated the role of ovarian oestradiol in the regulation of the seasonal antler cycle in female reindeer. Ovariectomized Norwegian reindeer living outdoors in northern Norway $\left(69^{\circ} \mathrm{N}\right)$ were treated with continuous-release subcutaneous Silastic implants containing oestradiol, which maintained the blood concentrations of oestradiol within the physiological range for the mating season from June to OctoberNovember. The treatment with oestradiol induced the synchronized maturation of the antlers and rapid cleaning of the velvet-like skin in August-September in the ovariectomized reindeer, a pattern very similar to that observed in ovary-intact controls living under the same conditions. The removal of the steroid implant in OctoberNovember caused the premature casting of the antlers in early winter in two of five animals, while the remainder cast at the normal time in spring; this response was seen whether the animals had received one or two oestradiol implants in autumn. The antlers developed by the ovariectomized, oestradiol-treated females were significantly heavier and carried more branches than the ovariectomized animals without oestradiol replacement, and were marginally heavier than the antlers of intact controls. These results support the view that oestradiol is the biologically active steroid secreted by the ovary in intact female reindeers that induces the normal development of the antlers. Oestradiol stimulates the growth and mineralization of the antler bone, the cleaning of the velvet, and suppresses the casting of the hard antlers. This endocrine control ensures that the hard antlers, which function as weapons, are retained throughout the autumn and winter when the females are normally pregnant and when competition between females over food in the snow is most intense; hence there is a reproductive advantage to explain the evolution of antlers in females.
\end{abstract}

\section{Introduction}

The hormonal regulation of the seasonal antler cycle in female reindeer (or caribou), Rangifer tarandus, is poorly understood. The circulating concentrations of testosterone are low throughout the year in females, so it is unlikely that testosterone regulates the antler cycle, as it does in males (Leader-Williams, 1979; Ryg, 1983). In females, the cleaning of the velvet from the antlers in autumn coincides with the onset of ovarian activity at the start of the mating season and the hard antlers are retained throughout the winter. Pregnant animals normally cast the old antlers soon after calving in spring, while non-pregnant individuals cast a few weeks earlier (Espmark, 1971; Gagnon and Barrette, 1992). Experimental studies have shown that ovariectomy in

*Present address: Department of Biology, University of Tromsø, 9037 Tromsø, Norway.

Received 28 April 1998
October, once the hard antlers have developed, causes premature casting of the antlers within as little as 4 weeks (Lincoln and Tyler, 1994). However, long-term ovariectomized females continue to develop and cast a new set of antlers each year, although the antler cycle is permanently abnormal since cleaning of the velvet occurs 1-3 months later than in intact females and is often incomplete, and the antlers tend to be readily broken in winter (Tandler and Grosz, 1913; Lincoln and Tyler, 1994). Overall, these observations indicate that increased secretion of ovarian hormones in autumn and winter plays an important role in controlling the seasonal development of hard antlers in female reindeer. The ovarian hormone, oestradiol, is a possible candidate since the circulating concentrations of oestradiol increase in autumn coincident with cleaning of the antlers (Lincoln and Tyler, 1994 ) and, on the basis of studies in other ungulates (whitetailed deer: Harder and Woolf, 1976; Plotka et al., 1977; domesticated sheep and goat: Challis and Linzell, 1971), oestradiol secretion is likely to be increased during 
pregnancy, which would account for the association between the time of parturition and antler casting in reindeer. Pharmacological doses of oestradiol induce calcification of the growing antler and cleaning of the velvet in males of other species (Goss, 1963, 1968; Fletcher, 1978; Bubenik, 1990). In addition, in female red deer (Cervus elaphus), where antler growth has been provoked by treatment with testosterone and local trauma to the antler pedicles, treatment with high concentrations of oestradiol or stilboestrol in autumn induces cleaning of the velvet and the subsequent casting of the hard antler (Jaczewski, 1990), although this does not occur in response to physiological concentrations of oestradiol in autumn in ovary-intact females (Lincoln, 1984).

The aim of the present study was to investigate the hypothesis that oestradiol is the important endocrine regulator of the antler cycle in female reindeer, by recording long-term changes in ovariectomized female reindeer treated chronically with oestradiol at physiological concentrations from June to October-November. The prediction was that treatment started during the early antler-growing phase would induce full maturation of the antlers and cleaning of the velvet, as it does in normal intact animals, while the sudden cessation of treatment in late autumn would trigger premature casting of the hard antlers.

\section{Materials and Methods}

\section{Animals}

Observations were made on female Norwegian semidomesticated reindeer from January 1989 to May 1995. The animals were maintained outdoors in adjacent enclosures at the Department of Arctic Biology, University of Tromsø, Norway $\left(69^{\circ} \mathrm{N}, 19^{\circ} \mathrm{E}\right)$, and were given a concentrated pelleted diet RF-71 (Jacobsen and Skjenneberg, 1979) or RF80 , with occasional supplies of lichen, and with water or snow ad libitum.

\section{Experimental group}

The experimental group consisted of five long-term ovariectomized female reindeer in which the antler cycle had been recorded since the time of ovariectomy in October 1989 (adult at ovariectomy, $n=4$; Lincoln and Tyler, 1994) and May 1989 (juvenile at ovariectomy, $n=1$; Lincoln and Tyler, 1992) until the start of the treatments with oestradiol in 1993. The animals were 4-7 years old in June 1993 (mean body weight: $81.4 \mathrm{~kg}$ ).

In Expt 1, the ovariectomized females were each given one Silastic implant (Dow Corning, Midland, MI) containing oestradiol for a period of 4 months in summer and autumn of 1993. The treatment with oestradiol was started on 21 June 1993 when all the ovariectomized animals were regenerating new antlers in velvet (old antlers cast 63-87 days earlier), and the treatment was ended on 21 October 1993 by the removal of the implant. The Silastic implants were constructed by packing powdered oestradiol into $4 \mathrm{~mm}$ diameter Silastic tubing and blocking the ends with Silastic sealant, as described by Karsch et al. (1973). Each implant (total length: $30 \mathrm{~mm}$; steroid compartment: $20 \mathrm{~mm}$ ) was inserted beneath the skin on the inside of the hind leg. The animals were sedated using an i.m. injection of $80-100 \mu \mathrm{g}$ medetomidine $\mathrm{kg}^{-1}$ body weight to aid the implant insertion and removal; the effect was subsequently reversed using a single injection of $400-500 \mu \mathrm{g}$ atipamezole $\mathrm{kg}^{-1}$ body weight (Farmos Group, Turku) (Tyler et al., 1990).

In Expt 2, the same five ovariectomized females were treated with Silastic implants containing oestradiol over the summer and autumn of 1994. On this occasion, each animal received one implant on 16-17 June 1994, and a second implant on 19 September 1994; both implants were removed on 21 November 1994. These manipulations were carried out using a local anaesthetic (xylocain; Astra, Sodertalje) injected into the skin at the site of implantation, and not with general sedation. This second treatment protocol with oestradiol was designed to provide a two-phase increase in the circulating concentrations of oestradiol that would mimic more closely the seasonal endocrine changes in intact female reindeer (Lincoln and Tyler, 1994).

In both experiments, the steroid implants were soaked in water for $24 \mathrm{~h}$ before insertion to avoid the brief peak in the circulating steroid concentration that follows insertion of an unsoaked capsule. Single Silastic implants of similar size produce mean peripheral oestradiol concentrations of approximately $5 \mathrm{pg} \mathrm{ml}^{-1}$ plasma in a variety of breeds of domesticated sheep (estimated weight $35-50 \mathrm{~kg}$ ), and maintain a relatively constant release for $>12$ months (Karsch et al., 1977; Webb et al., 1985). In the present study, a single blood sample was collected from the jugular vein of each oestradiol-implanted ovariectomized reindeer on 20 August 1993 (one implant) and on 21 November 1994 (two implants), and the plasma was separated and stored until the concentrations of oestradiol were measured by an ultrasensitive assay (Mann et al., 1995). The concentrations of oestradiol were $1.60 \pm 0.12$ and $3.20 \pm 0.19 \mathrm{pg} \mathrm{ml}^{-1}$ plasma (mean \pm SEM) for the one and two implant treatments, respectively, which is within the normal physiological range for intact female reindeer in late summer and autumn at the start of the mating season (Lincoln and Tyler, 1994).

Throughout 1993 and 1994, the state of the antlers of the oestradiol-treated ovariectomized reindeer was recorded every week to construct a profile of the annual antler cycle for each individual. Cast antlers were weighed and the volume was determined by immersion in water to calculate the average density. The length of all intact antlers was measured from the tip to the base along the outside curve of the antler, and the total number of branches (points) was recorded.

\section{Control groups}

Data for the patterns of antler development and casting, and the size and weight of the antlers in the ovariectomized reindeer from 1989 to 1993 (Lincoln and Tyler, 1994; N. J. C. Tyler, unpublished) were used to characterize fully the seasonal antler cycle of ovariectomized reindeer in the 
Table 1. Summary of antler cleaning and casting dates for the three categories of female reindeer, Rangifer tarandus

\begin{tabular}{|c|c|c|c|}
\hline & OVX, no treatment & OVX + oestradiol & Intact non-pregnant \\
\hline Date first antler begins to clean velvet & 19 October \pm 7.1 days $^{a}$ & 8 September \pm 3.3 days & 14 September \pm 5.5 days \\
\hline Date first antler cast & 11 March \pm 20.8 days & 13 February \pm 34.5 days & 11 April \pm 6.0 days \\
\hline
\end{tabular}

Values are mean \pm SEM, $n=5$.

"Significantly different from other groups $(P<0.005)$.

OVX, ovariectomized.

absence of steroid treatment (ovariectomy but no treatment). In addition, data on the seasonal patterns of antler development and replacement, and the other antler characteristics were available for five ovary-intact, nonpregnant female reindeer kept in adjacent paddocks at the research institute between 1989 and 1995 (intact nonpregnant group). These animals were of a similar age to the ovariectomized reindeer, and acted as controls living under the same conditions in captivity.

\section{Statistical analysis}

Where data on the timing of the antler cycle and other antler characteristics were available for more than 1 year for an individual reindeer, the mean value across years for that parameter was calculated for each individual, and this was used to determine the group mean \pm SEM. For example, the dates of first antler cast for the ovariectomized no-treatment group were based on data from 1990 to 1993; means were calculated for each individual and then for the group. This involved converting to a Julian date and reconverting to a calendar date \pm SEM in days once the group mean had been determined (Table 1). The corresponding values for the overall oestradiol-treated ovariectomized group were based on data from 1993 to 1995 , when the animals received the oestradiol implants. Similarly, the dates of first antler cast for the intact group were based on all data available between 1990 to 1995; means were calculated for each individual and then for the group. The differences between the groups for each antler parameter were assessed for significance using analysis of variance (ANOVA) and a one-tailed KruskalWallis test. Since the data for the untreated ovariectomized and oestradiol-treated ovariectomized groups were derived from the same animals, a further statistical comparison between these two treatments was carried out using paired Student's $t$ test.

\section{Results}

\section{Effect of oestradiol administration on antler cleaning}

The annual cycles in growth, cleaning and casting of the antlers in the five ovariectomized reindeer in 1992 (no treatment) and in 1993 (one implant of oestradiol) are illustrated (Fig. 1), along with data for five ovary-intact reindeer in 1992. In the ovariectomized animals receiving no oestradiol, the cleaning of the velvet from the antlers commenced in October and continued gradually over a period of 1-6 months during autumn and winter. In some individuals, the process was still incomplete by spring and tatters of dried skin were still adherent to the underlying antler bone. The treatment with one oestradiol implant (Expt 1, 1993), starting in June during the early growing phase, resulted in complete and rapid cleaning of the velvet in late August and early September in all animals. This began at least 6 weeks earlier than it did in animals not treated with steroid, and the synchronous cleaning pattern was very similar to that in the intact controls (Fig. 1). Antler maturation was essentially the same in the ovariectomized reindeer treated with oestradiol in 1994 (Expt 2), when a second oestradiol implant was introduced in September just before or during the cleaning of the antlers (Fig. 2).

The statistical analysis confirmed that cleaning of the antlers occurred significantly $(P<0.005)$ earlier in the years when the ovariectomized animals received oestradiol than they did during periods without treatment (Table 1), and the duration of the cleaning process was significantly shorter $(7.0 \pm 3.0$ versus $60.9 \pm 13.8$ days, for the combined oestradiol-treated ovariectomized versus untreated ovariectomized groups, respectively; $P<0.001$ ). There were no significant differences in the timing and pattern of cleaning between the oestradiol-treated ovariectomized reindeer and intact controls (Table 1). The appearance of the antlers of one ovariectomized reindeer before and after treatment with oestradiol is shown (Fig. 3).

\section{Effect of oestradiol removal on antler casting}

The oestradiol-treated ovariectomized reindeer were all in hard antler at the time the steroid implants were removed in October-November (Figs 1 and 2). Two of the five animals cast both hard antlers within 38 days of implant removal (implant removal to antler casting: range 21-38 days), while the others retained the antlers until close to the normal casting time in spring (implant removal to antler casting: range 89-161 days). The same animals that cast early in 1993 (after one oestradiol implant), also cast early in 1994 (after two oestradiol implants; Fig. 2), and the same animals that cast at the later date in the first trial cast close to the normal time in spring in the second trial. Overall, the difference between the casting dates in the ovariectomized reindeer, with and without previous treatment with oestradiol, was not quite significant (paired $t$ test, $P=0.07$; Table 1 ).

The eroded surface at the base of the cast antlers in the oestradiol-treated ovariectomized reindeer was markedly concave compared with the flat or convex casting surface in the intact controls (Fig. 4). The concave pattern characteristic 
(a)

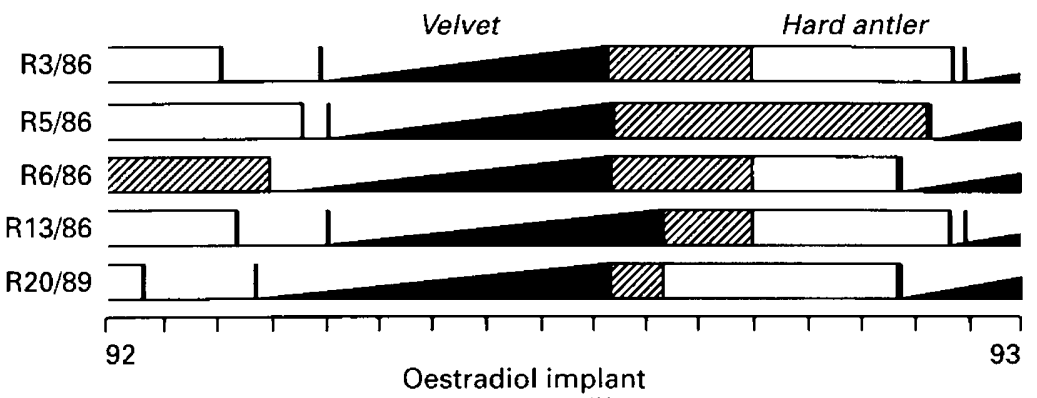

(b)

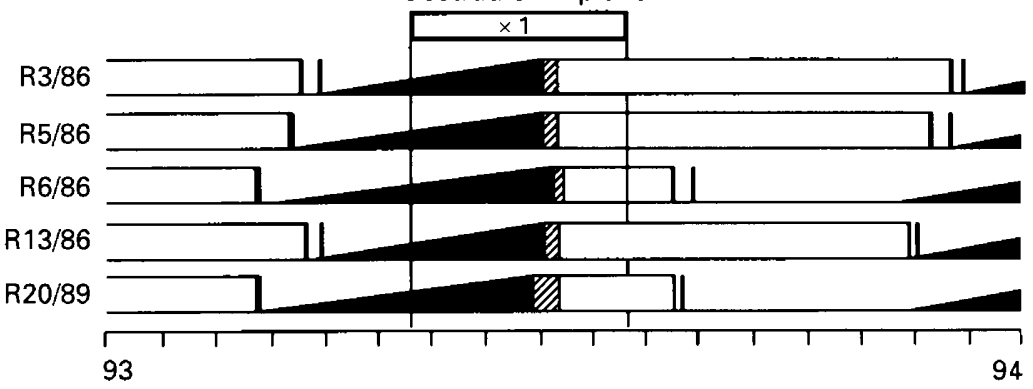

(c)

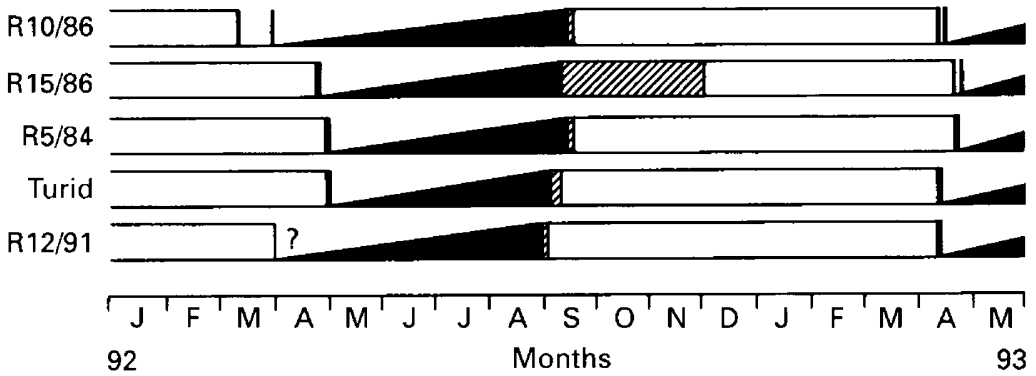

Fig. 1. The seasonal antler cycle in: (a) five long-term ovariectomized reindeer that received no treatment in 1992-1993; (b) the same five ovariectomized reindeer treated with one subcutaneous Silastic implant containing oestradiol from June to October (horizontal bar $\times 1$ ) in 1993-1994; and (c) five ovary-intact, non-pregnant female reindeer that received no treatment in 1992-1993. The stages of the antler cycle are shown as periods of growth in velvet $(\mathbb{\square})$, cleaning $(\mathbb{Z})$ and hard antler $(\square)$, terminating with the casting of the antlers (vertical lines represent individual antlers).

of ovariectomized animals was evident in the oestradioltreated ovariectomized animals that cast very soon after removal of the oestradiol implants (total period in hard antler: 62-97 days) and those that cast later (total period in hard antler: 197-226 days; Fig. 4 illustrates an example).

\section{Effect of oestradiol on antler size and branching}

The antlers developed by the oestradiol-treated ovariectomized animals were significantly $(P<0.005)$ heavier and had a greater number of fully formed branches (points) compared with the antlers developed by the untreated ovariectomized animals, and were marginally $(P<0.05)$ heavier and more elaborate than antlers of the intact controls (Fig. 5). There were no significant differences between the treatment groups in the length and density of the hard antlers (Fig. 5). Breakage of the hard antlers during the winter through contact with fences and during interactions with other animals was relatively common in the ovariectomized reindeer before treatment with oestradiol ( $47 \%$ annual cycles), but there were no recorded breakages after the supplementary oestradiol and none in the intact controls over the 5 years of observation.

\section{Discussion}

The results of the present study support the hypothesis that oestradiol is an important endocrine regulator of the antler cycle in female reindeer. The treatment of ovariectomized reindeer with oestradiol implants restored a relatively normal pattern of antler maturation with rapid and synchronous cleaning of the velvet in autumn. The replacement therapy produced circulating concentrations of oestradiol of $1.25-3.62 \mathrm{pg} \mathrm{ml}^{-1}$ blood plasma, which is within the physiological range for intact females during late summer and autumn at the start of the mating season 


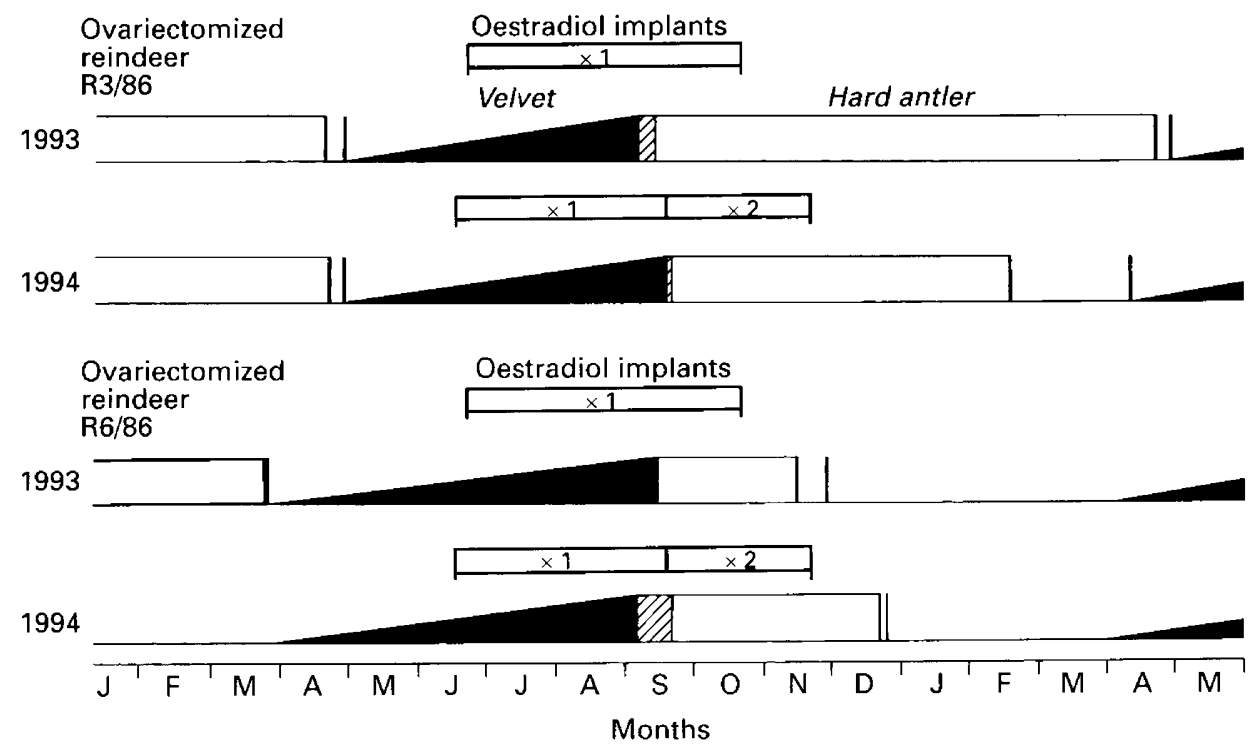

Fig. 2. The seasonal antler cycle in two individual long-term ovariectomized reindeer (R3/86 and R6/86) treated with one oestradiol implant in 1993, and two oestradiol implants in 1994. The timing of the treatments is indicated (horizontal bars $\times 1$ and $\times 2$ ). The stages of the antler cycle are shown as periods of growth in velvet $(\square)$, cleaning $(\mathbb{Z})$ and hard antler $(\square)$, terminating with the casting of the old antlers (vertical lines represent the individual antlers).
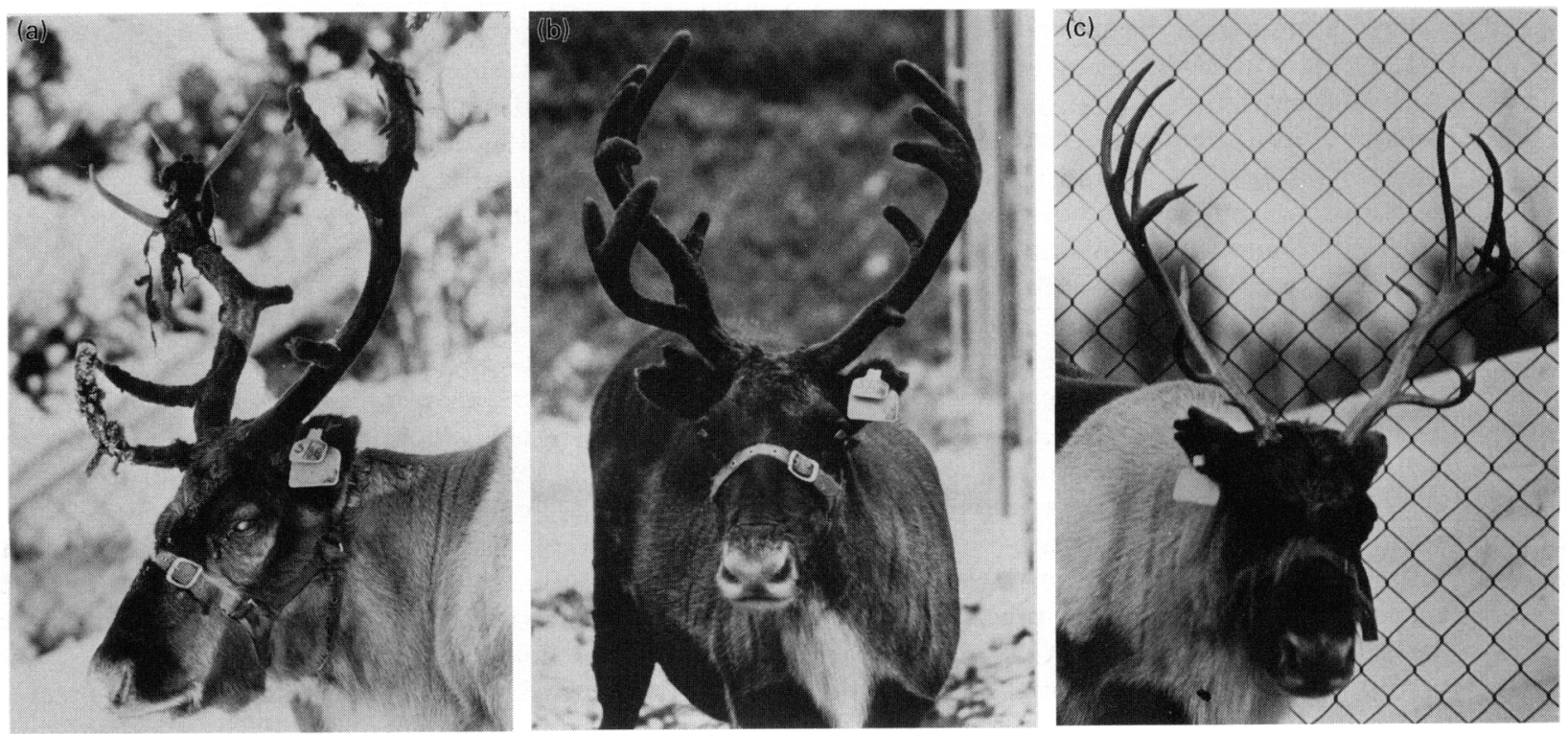

Fig. 3. Photographs of a long-term ovariectomized reindeer (R3/86) on (a) 12 October 1992 with no treatment when the cleaning of the velvet-like skin from the antler was just beginning (total of 11 antler points); (b) 19 August 1993 after 2 months treatment with one oestradiol implant when the new antlers were fully grown (cleaning of the antler velvet began 11 days later; total of 13 antler points); and (c) 23 October 1994 after 3 months treatment with one or later two oestradiol implants when the large hard antlers were fully formed (total of 16 antler points).

(Lincoln and Tyler, 1994). Since the cleaning of the velvet in the intact female reindeer normally coincides with the seasonal increase in secretion of oestradiol from the ovary at the onset of oestrous cyclicity, and the effect can be mimicked by the administration of exogenous oestradiol, it is most probable that oestradiol is the biologically active hormone that induces the final maturation of the antler to produce the dead, bony antler that functions as a weapon (Lincoln, 1994).

The reindeer is the only species of deer in which females as well as males normally develop antlers, although the antlers of females are relatively small. The species is also unique in that the antlers begin to develop soon after birth, and both 


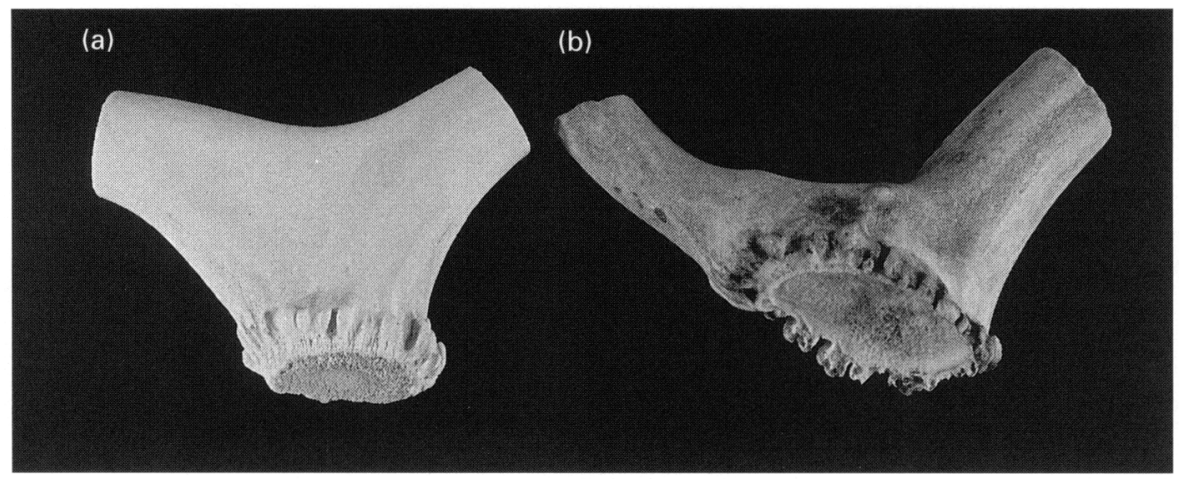

Fig. 4. Photographs of the base of the cast antler from (a) a representative ovary-intact control female reindeer cast in April 1994 showing the flat-convex casting surface, and (b) an oestradioltreated ovariectomized reindeer (R5/86) cast on 24 April 1994 showing the concave casting surface.

the initial growth of the antlers and their seasonal replacement persists in gonadectomized animals of either sex (females: Tandler and Grosz, 1913; Lincoln and Tyler, 1994; males: Skjenneberg and Slagsvold, 1968; Lincoln and Tyler, 1992). Thus, the growth of antlers per se is not a sexlimited characteristic. Nevertheless, it has been shown that the administration of testosterone to intact male reindeer induces premature maturation of the antlers and cleaning of the velvet (Ryg, 1983), as in males of other species (Goss, 1963; Bubenik, 1990), and the results of the present study demonstrate that the administration of oestradiol is similarly effective in female reindeer. This finding supports the view that, while the gonadal hormones are not essential for the development and replacement of the antlers in reindeer, they play a crucial role in synchronizing the antler cycle with the seasonal reproductive cycle (Lincoln and Tyler, 1994) and presumably dictate the dimorphism in antler size.

While the effects of sex steroids on the ossification and cleaning of the antler are well recognized, their stimulatory effects on antler growth and development are poorly described. In the present study, the antlers produced by the oestradiol-treated ovariectomized reindeer were almost twice as heavy and carried significantly more welldeveloped branches (points) than those produced in the years before the steroid treatment. This effect is unlikely to be due merely to the increase in age and physical size, since the ovariectomized animals were already fully physically mature before the steroid replacement was initiated, and the antlers that developed during the previous two years showed no age-dependent incremental change. The antlers produced by the ovariectomized reindeer during treatment with oestradiol were apparently physically stronger since none was broken during winter through contact with fences and during interactions with other animals, in contrast to before treatment when breakages were frequent. Overall, these observations support the view that oestradiol normally acts to promote the growth and morphological development of antlers, as well as regulating their terminal maturation. The cellular mechanisms by which sex steroids stimulate antler growth have not been investigated, but most probably involve the induction of anabolic and proliferative effects on the bone cells and the activation of growth factors, on the basis of studies of skeletal-derived osteoblasts that express both oestrogen and androgen receptors (Barzell, 1988; Eriksen et al., 1988; Colvard et al., 1989). Insulin-like growth factor I (IGF-I) is one candidate regulator, since IGF-I receptors are expressed in the growing tip of the antler in red deer and IGF-I may mediate the effects of growth hormone to induce the initiation of antler growth in spring (Suttie et al., 1985; Suttie and Fennessy, 1992). In osteoblasts from other species, oestradiol induces cell proliferation due, at least in part, to the local production of IGF-I and IGF binding proteins (Ernst et al., 1989; Kasperk et al., 1989). Thus, tissue concentrations of the growth factor within the growing antler may be modulated by the sex steroids to affect growth (Sempéré et al., 1989). These observations are in agreement with the hypothesis developed from studies in male red deer (Lincoln, 1971, 1992) that proposes that low concentrations of gonadal steroids (both androgens and oestrogens) secreted during the sexually inactive phase of the seasonal reproductive cycle stimulate growth and full morphological development of the regenerating antler, while high concentrations of sex steroids produced before the mating season induce the full mineralization of the antler bone and the cleaning of the velvet to produce the hard antler.

Since increased concentrations of sex steroids are required to maintain the hard antlers (Goss, 1963), one prediction of the present study was that cessation of the treatment with oestradiol once the ovariectomized animals had hard antlers would induce casting of the antlers, as occurs in female reindeer at the time of ovariectomy (Lincoln and Tyler, 1994) and as occurs after castration in male reindeer (Hadwen and Palmer, 1922; Skjenneberg and Slagsvolt, 1968) and in other species (Wislocki et al., 1947; Waldo and Wislocki, 1951; Goss, 1963; Lincoln et al., 1972; Sempéré et al., 1989). However, removal of the oestradiol implants caused two of five animals to cast prematurely within 6 weeks, while the others cast at the normal time in spring. This ability of some individuals to retain hard antlers in the absence of gonadal steroids, as well as the ability of untreated gonadectomized 
(a)

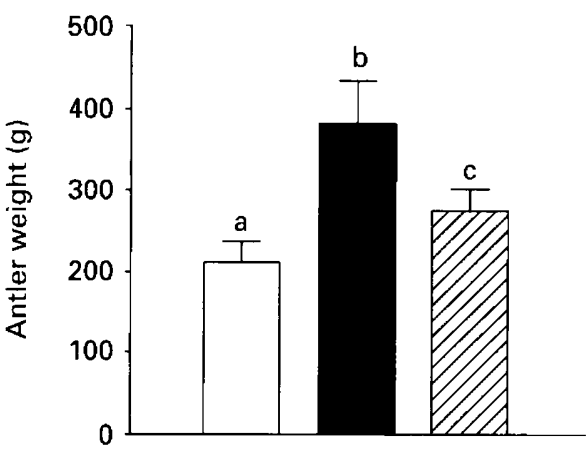

(b)

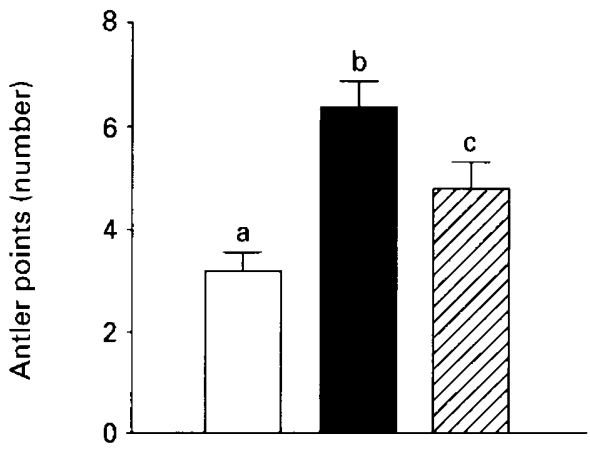

(c)

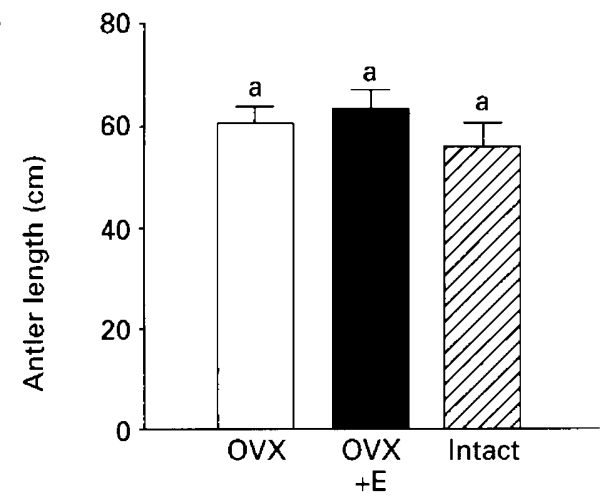

Fig. 5. Histograms showing the (a) antler weight, (b) antler points per antler, and (c) antler length in untreated ovariectomized (OVX), oestradiol-treated ovariectomized (OVX + E), and intact, non-pregnant control (Intact) reindeer. The values are means \pm SEM, $n=5$. For each parameter, groups denoted by a different letter $(\mathrm{a}, \mathrm{b}, \mathrm{c})$ are significantly different $(P<0.05$, ANOVA with KruskalWallis test).

reindeer to clean the antlers in winter partially or completely (Tandler and Grosz, 1913; Skjenneberg and Slagsvolt, 1968; Lincoln and Tyler, 1994) suggests that steroid hormones from other tissues, particularly the adrenal gland, may contribute to the regulation of the antler cycle (Bubenik et al., 1987). Androstenedione is present in the circulation of ovariectomized reindeer in winter, and acute stimulation of adrenal steroidogenesis provokes an increase in both androstenedione and testosterone secretion (Lincoln and Tyler, 1994). Therefore, adrenal steroids may also influence the development and retention of the hard antlers.

The erosion surface at the base of the cast antlers from the oestradiol-treated and untreated ovariectomized reindeer was concave, and quite distinct from the flat or convex surface of antlers from intact controls. A concave casting surface is also a feature of antlers from long-term castrated male reindeer, and in males of other species that have been induced to cast prematurely by castration (Wislocki et al., 1947; Goss, 1963). Casting occurs when osteoblasts migrate to the junction between the living pedicle and the dead tissue of the hard antler, triggered by the declining steroid environment (Goss et al., 1992). These cells erode the bone matrix progressively until the old antler is cast. One explanation for the shape of the erosion surface at the base of the cast antler is that the live-dead junction moves slowly down into the antler pedicle due to a process of 'die-back' and, if casting is triggered early during the hard-antler phase, erosion of the bone occurs higher into the base of the old antler to produce a concave casting surface (Lincoln, 1984). If this model is correct then the 'die-back' of the dead antler tissue must be delayed in ovariectomized and castrated reindeer since casting at the normal time in spring produces a concave base to the antler. This would be consistent with the observed delay in the overall maturation and cleaning of the antlers, compared with intact females. However, treatment with oestradiol induced normal rapid cleaning but still resulted in a casting surface similar to that of ovariectomized animals, thus the effects of sex steroids on cleaning and casting can be dissociated, and it is the presence of the steroid in the winter that determines the pattern of 'die-back' at the junction between the dead antler and the living pedicle.

In conclusion, this study provides strong experimental support for the hypothesis that oestradiol secreted by the ovary acts to induce and maintain the hard antler state in female reindeer. The effect of oestradiol is likely to be biphasic, with the steroid acting initially to stimulate growth and later to inhibit growth by terminally differentiating the antler tissues. Since the normal sequence of growth, ossification and cleaning occurred in the oestrogen-treated ovariectomized reindeer in the presence of a presumed constant blood concentration of oestradiol, a progressive change in steroid concentrations is not a prerequisit for the sequential maturation of the antler. The endocrine regulation of the antler in normal animals ensures that the antler cycle is synchronized to the seasonal reproductive cycle, and that the antlers are fully developed in autumn and winter, when females are normally pregnant, and when competition for food in deep snow can be most intense between them. The selective advantage of possessing an effective weapon used in intrasexual competition under the special conditions of the Arctic (Lincoln, 1994) provides an explanation for the evolution of antlers in female reindeer.

The authors are grateful to the Department of Arctic Biology for use of the animal facilities in Tromse, to A. Gjerdrum and H. Lian for the care of the reindeer and the help with the experimental treatments, to I. Swanston and I. Cooper for the expert technical assistance with the hormone assay, to T. Pinner and T. McFetters for the art work and to R. Webb (University of Nottingham) for the supply of oestradiol implants. This study was supported in part by the Norwegian Research Council for Science and the Humanities, the Norwegian Reindeer Husbandry Research Council (RFR) and the University of Tromsø. 


\section{References}

Barzel VS (1988) Estrogen in the prevention and treatment of postmenopausal osteoporosis. A review American Journal of Medicine 85 847-867

Bubenik GA (1990) Neuroendocrine regulation of the antler cycle. In Horns, Pronghorns and Antlers pp 265-297 Eds GA Bubenik and AB Bubenik. Springer-Verlag, New York

Bubenik GA, Pomerantz D, Schams D and Smith PS (1987) The role of androstenedione and testosterone in the reproduction and antler growth of a male white-tailed deer Acta Endocrinologia 144 147-152

Challis JRG and Linzell JL (1971) The concentration of total unconjugated oestrogens in plasma of pregnant goats Journal of Reproduction and Fertility $26401-404$

Colvard DS, Eriksen EF, Keeting PE, Wilson E, Lubahn DB, French FS, Riggs BL and Spelsberg TC (1989) Identification of androgen receptors in normal human osteoblast-like cells Proceedings of the National Academy of Sciences USA 86 854-857

Eriksen EF, Colvard DS, Berg NJ, Graham ML, Mann KG, Spelsberg TC and Riggs BL (1988) Evidence of estrogen receptors in normal human osteoblast-like cells Science 241 84-85

Ernst M, Heath JK and Rodan GA (1989) Estradiol effects on proliferation, messenger ribonucleic acid for collagen and insulin-like growth factor, and parathyroid hormone-stimulated adenylate cyclase activity in osteoblastic cells from calvariae and long bones Endocrinology 125 825-833

Espmark Y (1971) Antler shedding in relation to parturition in female reindeer Journal of Wildife Management 35 175-177

Fletcher TJ (1978) The induction of male sexual behaviour in red deer (Cervus elaphus $L$.) by administration of testosterone to hinds and estradiol- $17 \beta$ to stags Hormones and Behavior 11 74-88

Gagnon L and Barrette C (1992) Antler casting and parturition in wild female caribou Journal of Mammals $73440-442$

Goss RJ (1963) The deciduous nature of deer antlers. In Mechanisms of Hard Tissue Destruction pp 339-369 Ed. RF Sognnaes. Publication 75, American Association for the Advancement of Science, Washington DC

Goss RJ (1968) Inhibition of growth and shedding of antlers by sex hormones Nature 220 83-85

Goss RJ, Van Praagh A and Brewer P (1992) The mechanism of antler casting fallow deer Journal of Experimental Zoology 264 429-436

Hadwen S and Palmer LJ (1922) Reindeer in Alaska Department of Agriculture Bulletin 1089 1-2

Harder JD and Woolf A (1976) Changes in the plasma levels of oestrone and oestradiol during pregnancy and parturition in white-tailed deer journal of Reproduction and Fertility 47 161-167

Jacobson E and Skjenneberg S (1979) Experiments with different diets to reindeer. Feeding value of reindeer feed (RF-71) Scientific Reports of the Agricultural University of Norway 58 1-11

Jaczewski Z (1990) Experimental induction of antler growth. In Horns, Pronghorns and Antlers pp 371-395 Eds GA Bubenik and AB Bubenik. Springer-Verlag, New York

Karsch FJ, Dierschke DJ, Weick RF, Yamaji T, Hotchkiss J and Knobil E (1973) Positive and negative feedback control by estrogen of luteinizing hormone secretion in the rhesus monkey Endocrinology 92 799-804

Karsch FJ, Legan SJ, Hauger RL and Foster DL (1977) Negative feedback action of progesterone on tonic luteinzing hormone secretion in the ewe: dependence on the ovaries Endocrinology 101 800-806

Kasperk CH, Wergedal JE, Farley JR, Linkhart TA, Turner RT and Baylink
D) (1989) Androgens directly stimulate proliferation of bone cells in vitro. Endocrinology 124 1576-1578

Leader-Williams N (1979) Age-related changes in the testicular and antler cycles of reindeer, Rangifer tarandus. Journal of Reproduction and Fertility 57 117-126

Lincoln GA (1971) The seasonal reproductive changes in the red deer stag (Cerous elaphus) Journal of Zoology (London) 163 105-123

Lincoln GA (1984) Antlers and their regeneration - a study using hummels, hinds and haviers Proceedings of the Royal Society of Edinburgh 82B 243-259

Lincoln GA (1992) Biology of antlers Journal of Zoology (London) 226 517-528

Lincoln GA (1994) Teeth, horns and antlers: the weapons of sex. In The Differences Between the Sexes pp 131-158 Eds RV Short and E Balaban. Cambridge University Press, Cambridge

Lincoln GA and Tyler NJC (1992) Antler growth in male and female reindeer calves occurs in the absence of the gonads. In The Biology of Deer pp 493-498 Ed. RD Brown. Springer-Verlag, New York

Lincoln GA and Tyler NJC (1994) Role of gonadal hormones in the regulation of the seasonal antler cycle in female reindeer, Rangifer tarandus. Journal of Reproduction and Fertility 101 129-138

Lincoln GA, Guiness F and Short RV (1972) The way in which testosterone controls the social and sexual behaviour of the red deer Hormones and Behavior 3 375-396

Mann GE, Lamming GE and Fray MD (1995) Plasma oestradiol and progesterone during early pregnancy in the cow and the effect of treatment with buserilin Animal Reproduction Science 37 121-131

Plotka ED, Seal US, Verme LJ and Ozoga JJ (1977) Reproductive steroids in the white-tailed deer (Odocoileus virginianus borealis) II. Progesterone and estrogen levels in peripheral plasma during pregnancy Biology of Reproduction 17 78-83

Ryg $\mathbf{M}$ (1983) Effect of testosterone on antler growth in yearling male reindeer Rangifer 36-9

Sempéré AJ, Grimberg R, Silve C, Tau C and Garabedian M (1989) Evidence for extrarenal production of 1,25-dihydroxyvitamin $D$ during physiological bone growth: in vivo and in vitro production by deer antler cells Endocrinology $1252312-2319$

Skjenneberg S and Slagsvold L (1968) Reindeer Husbandry pp 22-27 Universitersforlaget, Oslo

Suttie JM and Fennessy PF (1992) Recent advances in the physiological control of velvet antler growth. In The Biology of Deer pp 471-486 Ed. RD Brown. Springer-Verlag, New York

Suttie JM, Gluckman PD and Butler JH (1985) Insulin-like growth factor 1 (IGF-1), antler-stimulating hormone? Endocrinology 116 846-848

Tandler J and Grosz S (1913) Die biologischen Grundlagen der Sekundaren Geschlechtscharaktere pp 25-27 Springer-Verlag, Berlin

Tyler NJC, Hotvedt R, Blix AS and Sorensen D (1990) Immobilization of Norwegian reindeer (Rangifer tarandus tarandus) and Svalbard reindeer (Rangifer tarandus platyrhynchus) with medetomidine and medetomidineketamine and reversal of immobilization with atipamezole Acta Veterinaria Scandinavica $31479-488$

Waldo $M$ and Wislocki GB (1951) Observations on the shedding of the antlers of Virginia deer (Odocoileus virginiana borealis) American Journal of Anatomy $88351-369$

Webb R, Baxter G, Preece RD, Land R and Springbett AJ (1985) Control of gonadotrophin release in Scottish Blackface and Finnish Landrace ewes during seasonal anoestrus Journal of Reproduction and Fertility 73 369-378

Wislocki GB, Aub JC and Waldo CM (1947) The effect of gonadectomy and administration of testosterone propionate on the growth of antlers in male and female deer Endocrinology 40 202-224 